\title{
Mechanical properties of friction stir welded aluminum alloys 5083 and 5383
}

\author{
Jeom Kee Paik
}

\author{
Lloyd's Register Educational Trust (LRET) Research Centre of Excellence, Pusan National University, Busan, Korea
}

\begin{abstract}
The use of high-strength aluminum alloys is increasing in shipbuilding industry, particularly for the design and construction of war ships, littoral surface craft and combat ships, and fast passenger ships. While various welding methods are used today to fabricate aluminum ship structures, namely gas metallic arc welding (GMAW), laser welding and friction stir welding (FSW), FSW technology has been recognized to have many advantages for the construction of aluminum structures, as it is a low-cost welding process. In the present study, mechanical properties of friction stir welded aluminum alloys are examined experimentally. Tensile testing is undertaken on dog-bone type test specimen for aluminum alloys 5083 and 5383. The test specimen includes friction stir welded material between identical alloys and also dissimilar alloys, as well as unwelded (base) alloys. Mechanical properties of fusion welded aluminum alloys are also tested and compared with those of friction stir welded alloys. The insights developed from the present study are documented together with details of the test database. Part of the present study was obtained from the Ship Structure Committee project SR-1454 (Paik, 2009), jointly funded by its member agencies.
\end{abstract}

KEY WORDS: High-strength aluminum alloys; Aluminum alloy 5083; Aluminum alloy 5383; Friction stir welding; Fusion welding

\section{INTRODUCTION}

The use of high-strength aluminum alloys in the shipbuilding industry is increasing; The benefits of using aluminum rather than steel include its lighter weight, which helps increase cargo capacity and/or reduce power requirements, excellent corrosion resistance and low maintenance (Sielski, 2007, 2008; Paik et al., 2008).

Various welding methods are used today to fabricate aluminum ship structures, namely, gas metal arc welding (GMAW), laser welding and friction stir welding (FSW). Among them, FSW has also been recognized as a very attractive joining method for aluminum structures because of its many superior features, such as excellent joint performance, small degree of initial imperfections, low level of energy consumption and lack of harmful emissions (Dawes \& Thomas, 1995). FSW technology has been applied successfully to various aluminum structures, such as railcars, automobiles and bridges (Thomas \& Nicholas, 1997; Midling et al., 1998; Sanderson et al., 2000).

FSW technology was developed in 1991 by the Welding Institute in the U.K. (Thomas et al., 1991, 1995). FSW is a

Corresponding author: Jeom Kee Paik

e-mail:jeompaik@pusan.ac.kr solid-state joining process that is particularly suitable for aluminum alloys that often face problems with fusion welds, such as cracks, porosity, distortion or softening. This technology has been recognized to have many advantages for the construction of aluminum structures, as it is a low-cost welding process. Aluminum alloys tend to show cracks and porosity after fusion welding, but FSW minimizes such problems because of the low input of total heat. The use of protective gases, e.g., for toxic shielding, may be unnecessary.

There have, of course, been useful studies that characterize the mechanical properties of FSW aluminum alloys (e.g., Rhodes et al., 1997; Hagstrom \& Sandstrom, 1998; Hashimoto et al., 1998; Mahoney et al., 1998; Biallas et al., 1999) and compare the properties of base and welded metals. A large number of studies on the strength performance of FSW aluminum structural details under fatigue conditions have also been undertaken (e.g., Kamioka \& Okubo, 2005; Kramer, 2007).

The applications of FSW technologies for shipbuilding were studied by Thomas (1998) and Thomas et al. (2002, 2005), among others. Colligan (2004) presented FSW applications for ship design and construction, together with a discussion of the use of FSW technology in the United States, and indicated that it is capable of reducing construction costs and welding distortion and improving durability in comparison with fusion welding. 
Peel et al. (2003) investigated the mechanical properties and residual stresses of a FSW aluminum 5083 test specimen, and concluded that these properties are governed by the thermal input rather than by the mechanical deformation caused by the FSW tool.

As we have seen, some useful studies that deal with micro-structural and fatigue issues in FSW aluminum structures have been undertaken. However, there is still a lack of studies on the characterization of material properties for FSW high-strength aluminum alloys such as aluminum 5083 and 5383, which are used for shipbuilding.

The aim of the present study is to experimentally examine the mechanical properties of friction stir welded aluminum alloys. Two types of aluminum alloys, i.e., 5083 and 5383 which are typical alloys used for shipbuilding, are considered. Tensile coupon testing is undertaken with dogbone type test specimen. To prepare the test specimen, FSW is performed between identical alloys and also between dissimilar alloys. Fusion welding is also applied for the purpose of comparison.

The insights and conclusions developed from the present study are documented together with details of the test database.

\section{FUSION WELDS VERSUS FRICTION STIR WELDS FOR ALUMINUM STRUCTURES: AN OVERVIEW}

\section{Classification of Welding Processes}

Although a large number of methods for joining metals are available today, they may be classified into the following five basic categories (Masubuchi, 1980).

- Fusion welding, e.g., gas metal arc welding (GMAW), gas tungsten arc welding (GTAW)

- Electrical-resistance welding

- Solid-phase welding, e.g., friction stir welding (FSW)

- Liquid-solid phase joining

- Adhesive bonding

In the fusion-welding process, the parts to be joined are heated until they melt together, and pressure is not a requisite. Examples of fusion welding include gas welding, arc welding, electron-beam welding and laser welding. Fusion welds that use inert gases, such as gas metal arc welding (GMAW) or gas tungsten arc welding (GTAW), are often applied to join aluminum structures.

In the electrical-resistance welding process, heating is firstly introduced via the passage of an electric current through the parts to be welded, followed by the application of pressure. Examples of electrical-resistance welding include spot welding, upset welding and percussion welding.

The solid-phase welding process is similar to that of electrical-resistance welding in terms of the application of pressure, but the metals to be joined are not melted, except for the very thin layers near the surfaces to be joined.
Examples of solid-phase welding include friction welding, forge welding and pressure welding. In this regard, FSW can be considered a type of solid-phase welding.

In the liquid-solid phase joining process, the parts to be joined are heated to a temperature lower than their melting points, and a dissimilar molten metal is then added to form a solid joint upon cooling. Examples of liquid-solid phase joining include brazing and soldering.

Finally, the adhesive bonding process makes use of the molecular attraction exerted between the surface to be bonded and the adhesive. Examples of such bonding include animal and vegetable glues, cements, asphaltums and various plastics (e.g., epoxy).

It should be noted that the processes of the first three categories are termed 'welding', whereas those of the latter two are often termed 'joining'.

\section{Fusion Welds}

Although various fusion-weld technologies are used in the fabrication of large-sized metal structures, inert gasoriented fusion welds are today the most popular in the construction of aluminum structures.

Fusion-weld technology provides a cost-effective tool in terms of speed, accuracy and weld-joint performance in the fabrication of such structures. However, a number of issues arise from the use of fusion welds in aluminum alloys for marine applications, such as 5000's or 6000's series alloys, including fabrication-related initial imperfections and a subsequent reduction in strength performance. Collette (2007) presented an excellent review of the impact of fusion welds in association with the ultimate strength performance of aluminum structures.

\section{Friction Stir Welds}

Fig. 1 illustrates a schematic of the FSW process which applies a solid-phase welding. The metal plates to be joined are clamped onto a rigid backing body. This set-up is necessary to avoid any movement of the target plates during the welding process, such as movement in the longitudinal, transverse and lateral directions during pressing and plunging. The tip of the FSW tool, with a specially designed and profiled probe called a pin and shoulder is rotated under sufficient downward force at high speed, and then moves slowly along the joint line.

- Step 1: Set-up the target plates to be joined, which are clamped onto a rigid backing body.

- Step 2: Equip the machine with the FSW tool (pin) and place it over the starting point of the joint.

- Step 3: Plunge the rotating FSW tool under sufficient downward force.

- Step 4: After touchdown, heat and plasticize the local material at the starting point of the joint.

- Step 5: Move the FSW tool along the joint line, thus transporting the plasticized material around the rotating pin. 
The pin size (e.g., diameter and length), shoulder width, and rotating and forwarding speed of the FSW tool are chosen based on the properties of the target plates to be joined, such as plate thickness, material type and others.

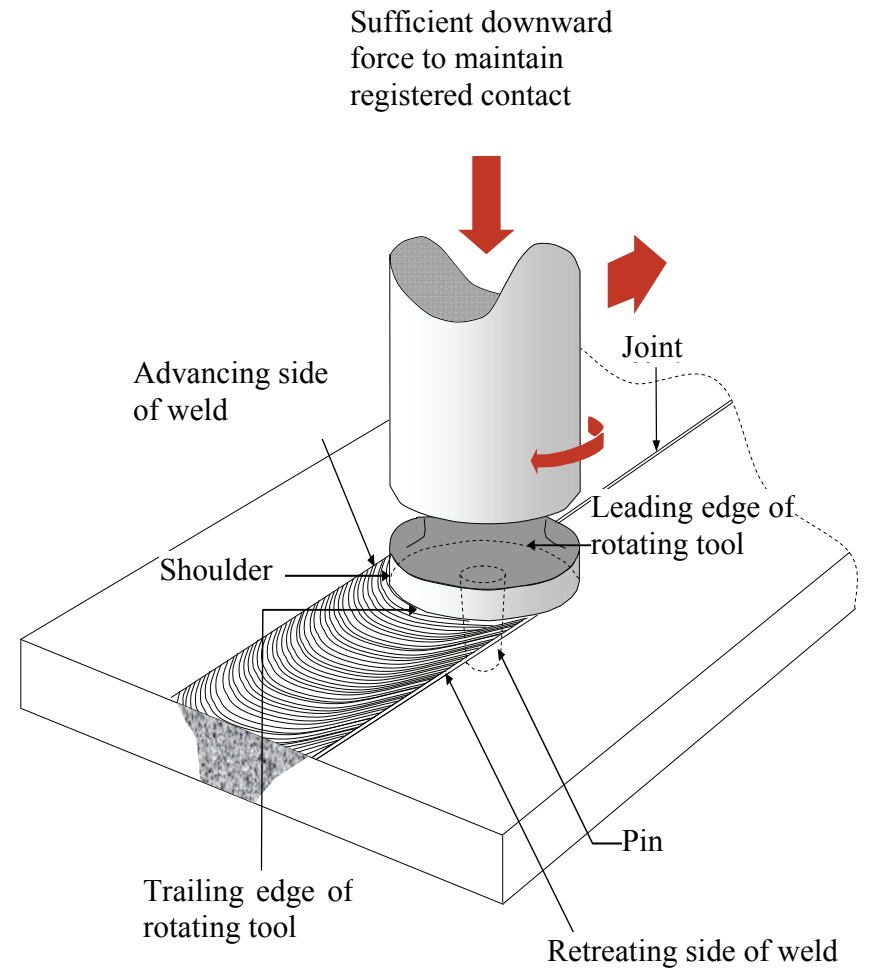

Fig. 1 Schematic of the FSW process (Thomas et al., 1991).

\section{TENSILE COUPON TEST}

Tensile coupon tests were carried out to identify the mechanical properties of the base material and the material in the welded parts. Fig. 2 shows the dimensions of the tensile coupon test specimen in conjunction with the American Society for Testing and Materials (ASTM) standards.

It should be noted that the mechanical properties of rolled alloys may differ from those of extruded alloys because their production process is different. In ship aluminum-stiffened panels, plating is made of rolled alloys, and the stiffeners are usually made of extruded alloys. Therefore, the test specimens corresponding to the plate part and extrusions need to be prepared for testing. For the latter, only the material in the stiffener web part was tested in the present study.

Three types of specimens with plate thicknesses of $6 \mathrm{~mm}$ were cut out of the plate part, namely, in the longitudinal (rolled), transverse and diagonal directions, whereas only one type of specimen with a plate thickness of $4 \mathrm{~mm}$ or $6 \mathrm{~mm}$ was taken from the extrusions in the length direction.

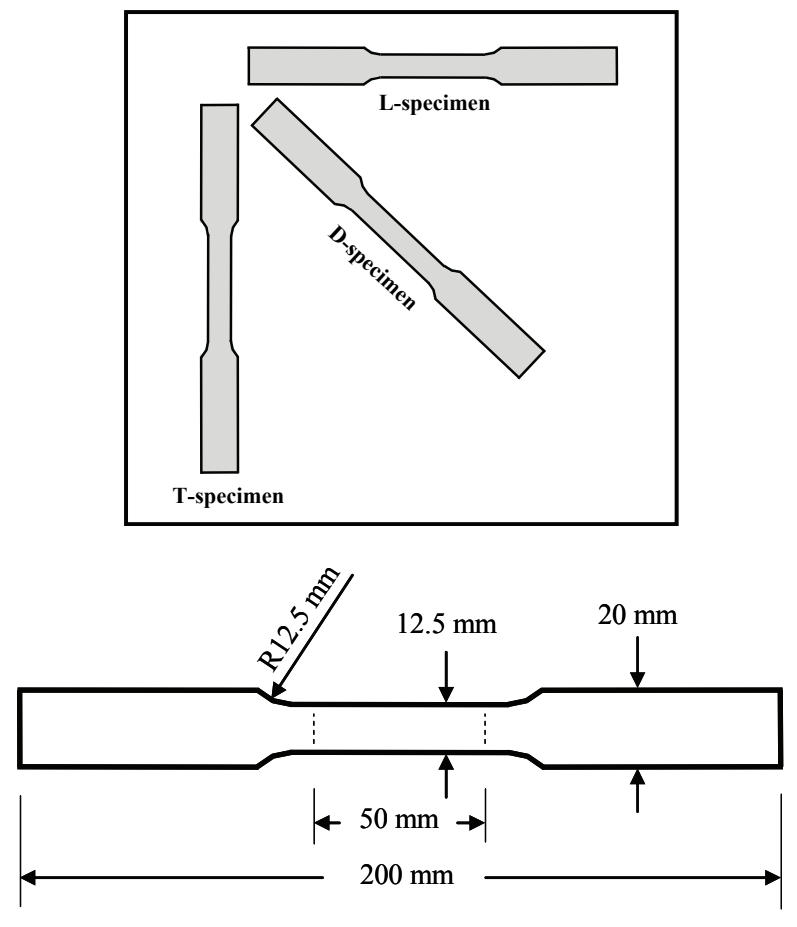

(a) Rolled plate part

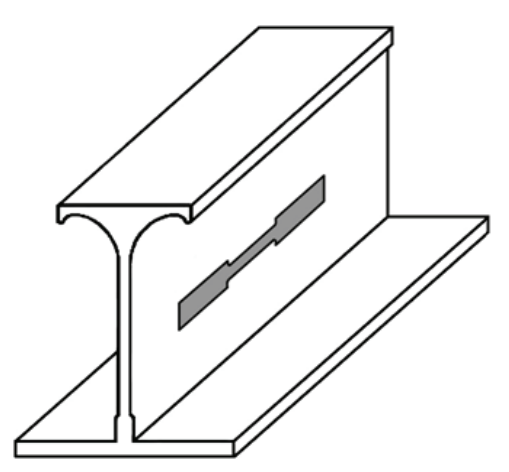

(b) Extruded web part

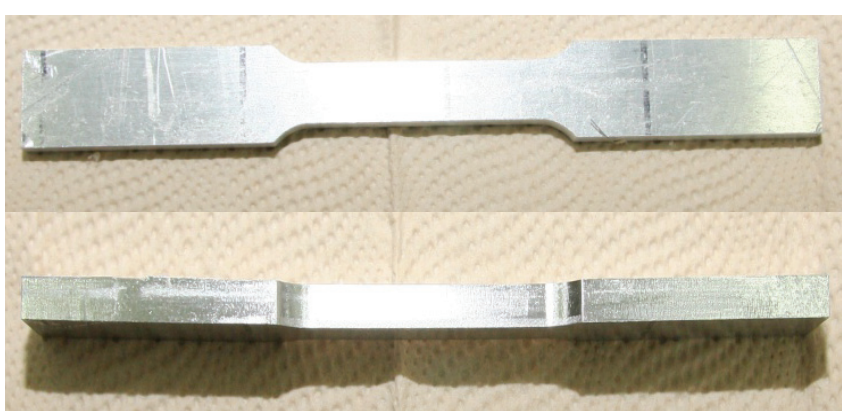

(c) Photos of sample tensile coupon test specimens

Fig. 2 Specimen of tensile coupon tests for the mechanical property characterization of the base material. 


\section{MECHANICAL PROPERTIES OF BASE ALLOYS}

Table 1 lists the chemical composition of all of the alloys investigated in the present study, which is equivalent to that of the typical aluminum alloys used in marine applications. It should be noted that the chemical composition of rolled plates differs from that of extrusions.

Fig. 3 shows the relationships between the engineering stress and the engineering strain of rolled plate aluminum 5083-H112, as obtained from the tensile coupon tests, where some materials were tested with multiple test specimens cut out in the same direction. Similar relationships were obtained for other types of materials, but with different mechanical properties as indicated in Table 2. Table 3 lists the minimum requirements of the mechanical properties of the base materials, as specified by the classification societies (Alcan, 2004; ABS, 2006; LR, 2008). It is observed that the mechanical properties of 5383 alloys do not meet the minimum requirements specified by Alcan (2004), while the materials were procured directly from Alcan France.

Table 1 Chemical composition (wt. \%) of aluminum alloys used in the present study.

\begin{tabular}{|c|c|c|c|c|c|c|c|c|c|}
\hline Alloy \& Temper & $\mathrm{Si}(\%)$ & $\mathrm{Fe}(\%)$ & $\mathrm{Cu}(\%)$ & $\mathrm{Mn}(\%)$ & $\operatorname{Mg}(\%)$ & $\mathrm{Cr}(\%)$ & $\mathrm{Zn}(\%)$ & $\operatorname{Ti}(\%)$ & $\operatorname{Zr}(\%)$ \\
\hline $5083-\mathrm{H} 112(\mathrm{R})^{1)}$ & 0.12 & 0.29 & 0.014 & 0.65 & 4.55 & 0.088 & 0.006 & 0.031 & 0.0 \\
\hline $5083-\mathrm{H} 112(\mathrm{E})^{1)}$ & 0.14 & 0.12 & 0.010 & 0.64 & 4.56 & 0.080 & 0.010 & 0.030 & 0.0 \\
\hline $5083-\mathrm{H} 116(\mathrm{R})^{2)}$ & $\begin{array}{c}\text { Max. } \\
0.40\end{array}$ & $\begin{array}{c}\text { Max. } \\
0.40\end{array}$ & $\begin{array}{c}\text { Max. } \\
0.10\end{array}$ & $\begin{array}{c}0.4 \\
\sim 1.0\end{array}$ & $\begin{array}{c}4.0 \\
\sim 4.9\end{array}$ & $\begin{array}{c}0.05 \\
\sim 0.25\end{array}$ & $\begin{array}{c}\text { Max. } \\
0.25\end{array}$ & $\begin{array}{c}\text { Max. } \\
0.15\end{array}$ & 0.0 \\
\hline 5383-H112 (E) $)^{2)}$ & $\begin{array}{c}\text { Max. } \\
0.25\end{array}$ & $\begin{array}{c}\text { Max. } \\
0.25\end{array}$ & $\begin{array}{c}\text { Max. } \\
0.20\end{array}$ & $\begin{array}{c}0.7 \\
\sim 1.0\end{array}$ & $\begin{array}{c}4.0 \\
\sim 5.2\end{array}$ & $\begin{array}{c}\text { Max. } \\
0.25\end{array}$ & $\begin{array}{c}\text { Max. } \\
0.40\end{array}$ & $\begin{array}{c}\text { Max. } \\
0.15\end{array}$ & $\begin{array}{c}\text { Max. } \\
0.20\end{array}$ \\
\hline 5383-H116 (R) $)^{1)}$ & 0.091 & 0.24 & 0.077 & 0.82 & 4.97 & 0.088 & 0.11 & 0.011 & 0.002 \\
\hline Al6082-T6 (E) $)^{1)}$ & 1.22 & 0.22 & 0.07 & 0.69 & 1.05 & 0.19 & 0.01 & 0.03 & 0.0 \\
\hline
\end{tabular}

Note: ${ }^{1)}$ Tested by Alcoa Korea, ${ }^{2)}$ Provided by Alcan France, $(\mathrm{E})=$ extruded, $(\mathrm{R})=$ rolled.

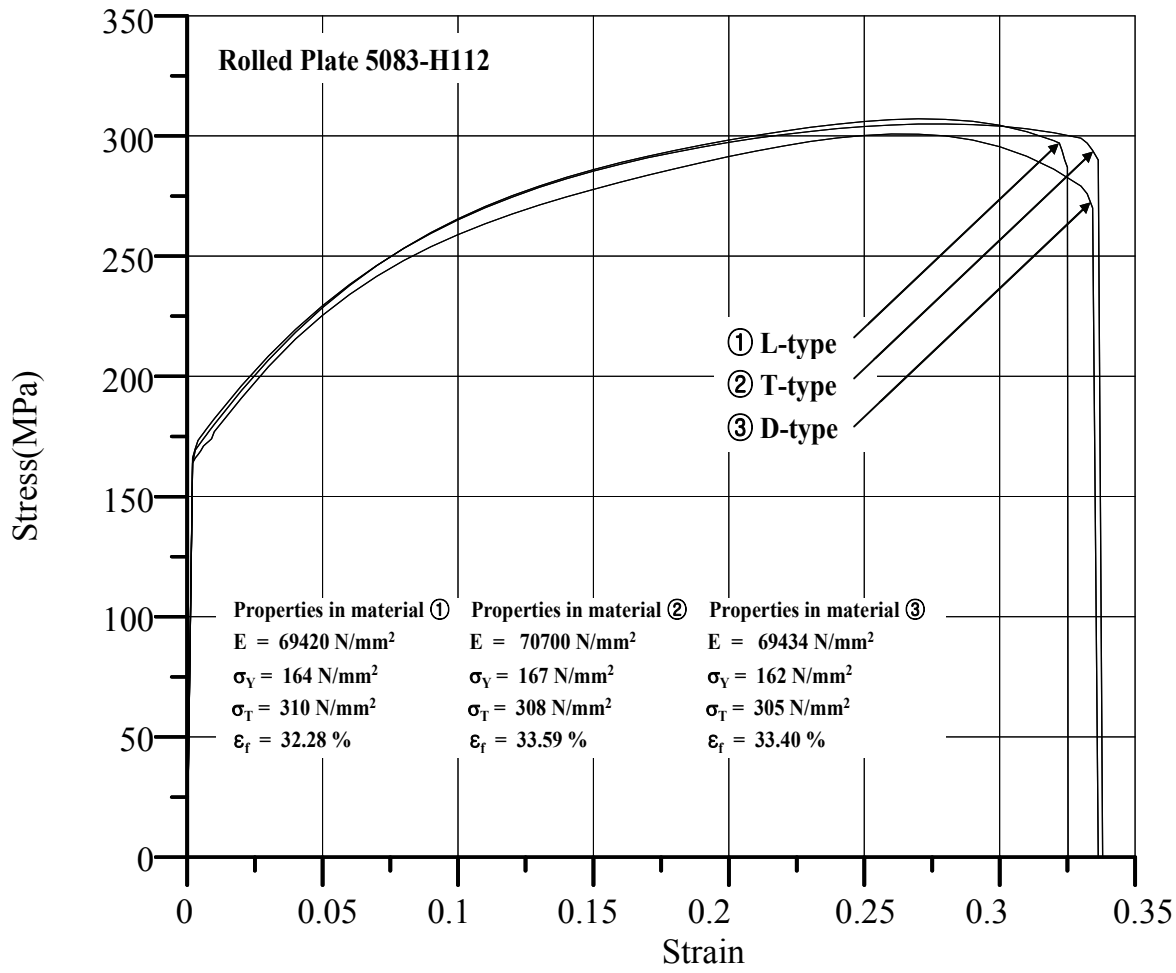

Fig. 3 The stress versus strain curves for the aluminium base material - 5083-H112 (rolled) - obtained from the tensile coupon tests. 
Table 2 Summary of the mechanical properties of the aluminum alloys (base material), obtained from the tensile coupon tests.

\begin{tabular}{|c|c|c|c|c|c|}
\hline Material & Specimen & $\mathrm{E}\left(N / m m^{2}\right)$ & $\sigma_{\mathrm{Y}}\left(N / \mathrm{mm}^{2}\right)$ & $\sigma_{\mathrm{T}}\left(N / \mathrm{mm}^{2}\right)$ & Elongation $(\%)$ \\
\hline \multirow{3}{*}{$5083-\mathrm{H} 112(\mathrm{R})(\mathrm{t}=6 \mathrm{~mm})$} & L-type & 69420 & 164 & 310 & 32.28 \\
\hline & T-type & 70700 & 167 & 308 & 33.59 \\
\hline & D-type & 69434 & 162 & 305 & 33.40 \\
\hline \multicolumn{2}{|l|}{ Average } & 69856.8 & 167.2 & 307.67 & 33.09 \\
\hline \multirow{2}{*}{$5083-\mathrm{H} 112(\mathrm{E})(\mathrm{t}=6 \mathrm{~mm})$} & L-type 1 & 70231 & 132 & 258 & 23.58 \\
\hline & L-type 2 & 70149 & 148 & 271 & 19.98 \\
\hline \multicolumn{2}{|l|}{ Average } & 70190 & 140 & 264.5 & 21.78 \\
\hline $5083-\mathrm{H} 116(\mathrm{R}) \quad(\mathrm{t}=6 \mathrm{~mm})$ & T-type & 73129 & 239 & 353 & 21.4 \\
\hline \multirow{2}{*}{$5383-\mathrm{H} 112(\mathrm{E})(\mathrm{t}=6 \mathrm{~mm})$} & L-type 1 & 69911 & 159 & 282 & 18.37 \\
\hline & L-type 2 & 70149 & 148 & 282 & 18.85 \\
\hline \multicolumn{2}{|l|}{ Average } & 70030 & 153.5 & 282 & 18.61 \\
\hline \multirow{3}{*}{$5383-\mathrm{H} 116(\mathrm{R}) \quad(\mathrm{t}=6 \mathrm{~mm})$} & L-type 1 & 70751 & 194 & 348 & 26.72 \\
\hline & L-type 2 & 70427 & 193 & 326 & 24.73 \\
\hline & T-type & 69887 & 215 & 352 & 25.64 \\
\hline \multicolumn{2}{|l|}{ Average } & 70355.3 & 207.9 & 342 & 25.85 \\
\hline 6082-T6 (E) $(\mathrm{t}=4 \mathrm{~mm})$ & L-type & 68359 & 304 & 306 & 11.53 \\
\hline 6082-T6 (E) $\quad(\mathrm{t}=6 \mathrm{~mm})$ & L-type & 68723 & 343 & 359 & 12.9 \\
\hline
\end{tabular}

Note: $(\mathrm{R})=$ rolled; $(\mathrm{E})=$ extruded; $\mathrm{E}=$ elastic modulus; $\sigma_{\mathrm{Y}}=$ yield strength; $\sigma_{\mathrm{T}}=$ ultimate tensile strength; L-type $=$ Longitudinal; T-Type $=$ Transverse; D-type $=$ Diagonal .

\section{MECHANICAL PROPERTIES OF WELDED ALLOYS}

To characterize the mechanical properties of the welded aluminum alloys, butt-joined specimens with a plate thickness of $6 \mathrm{~mm}$ were prepared via both the fusion-welding and friction stir welding (FSW) processes, as shown in Fig. 4. The condition of each weld is as follows.

- Fusion weld: Filler metal - 5183 aluminum alloy, diameter of filler wire $-1.2 \mathrm{~mm}$, shield gas $-100 \%$ Ar. inert gas, welding speed $-450 \mathrm{~mm} / \mathrm{min}$, electricity $-183 \mathrm{~A}$ and $21 \mathrm{~V}$, torch angle -50 degrees, welding progress angle -80 degrees.

- Friction stir weld: Rotating speed of FSW tool - 1500 RPM, forwarding speed of FSW tool $-4 \mathrm{~mm} / \mathrm{s}$, weld temperature - approximately $370^{\circ} \mathrm{C}$, FSW tool size $-d_{1}=4 \mathrm{~mm}, d_{2}=5$ $m m, d_{3}=15 \mathrm{~mm}, h=5.4 \mathrm{~mm}$, with the nomenclature in Fig.5.
The tensile coupon test specimens for the butt-welds were prepared for the combination of dissimilar alloys as well as for the identical alloys as follows.

- 5083-H112+ 5083-H112

- 5383-H116+ 5383-H116

- 5083-H112+ 5383-H116

Fig. 6 shows the engineering stress versus engineering strain curves of the butt-welded aluminum alloys, as obtained from the tensile coupon tests. Multiple test specimens with the same weld condition were prepared. It is observed that a somewhat significant deviation exists in elongation of friction stir-welded region. A comparison of these curves for welded aluminum alloys fabricated by fusion welding and by FSW is also shown in this figure. It is found that the mechanical properties of aluminum material fabricated by friction stir welding are equivalent to or can be better than those by fusion welding. 
Table 3 Minimum requirements for the mechanical properties of aluminum alloys - base material (ABS, 2006; Alcan, 2004).

\begin{tabular}{|c|c|c|c|c|}
\hline Material & Thickness $(\mathrm{mm})$ & $\sigma_{\mathrm{Y}}\left(N / m m^{2}\right)$ & $\sigma_{\mathrm{T}}\left(N / m m^{2}\right)$ & Elongation in $50 \mathrm{~mm}(\%)$ \\
\hline 5083-H111(E) & $\leq 130$ & 165 & 275 & - \\
\hline \multirow[t]{2}{*}{ 5083-H112 (R) } & $6.5-38.0$ & 124.5 & 275.4 & 12 \\
\hline & $38.1-76.5$ & 117.6 & 268.5 & 12 \\
\hline 5083-H112 (E) & - & 109.8 & 268.5 & 12 \\
\hline \multirow[t]{2}{*}{ 5083-H116 (R) } & $1.6-38.0$ & 213.6 & 302.8 & 10 \\
\hline & $38.1-76.5$ & 199.9 & 282.2 & 10 \\
\hline \multirow[t]{2}{*}{ 5083-H321 (R) } & $1.6-38.0$ & 213.6 & 302.8 & 10 \\
\hline & $38.1-76.5$ & 199.9 & 282.8 & 10 \\
\hline 5086-H116(R) & all & 195 & 275 & - \\
\hline 5383-H111 (R) & $3.0-5.0$ & 142.1 & 284.2 & 17 \\
\hline 5383-H111 (E) & - & 145.0 & 290.1 & 17 \\
\hline 5383-H112 (E) & - & 190 & 310 & 13 \\
\hline 5383-H116 (R) & $<20$ & 215 & 305 & 10 \\
\hline 5383-H321 (R) & $3.0-5.0$ & 215.6 & 298.9 & 10 \\
\hline 5454-H111(E) & $\leq 130$ & 130 & 230 & - \\
\hline 5456-H116(R) & $4.0-12.5$ & 230 & 315 & - \\
\hline 6061-T6(E) & all & 240 & 260 & - \\
\hline 6082-T6(E) & all & 262 & 310 & - \\
\hline
\end{tabular}

Note: $(\mathrm{R})=$ rolled; $(\mathrm{E})=$ extruded; $\mathrm{E}=$ elastic modulus; $\sigma_{\mathrm{Y}}=$ yield strength; $\sigma_{\mathrm{T}}=$ ultimate tensile strength; minimum requirement of elastic modulus is commonly $70,000 \sim 71,000\left(\mathrm{~N} / \mathrm{mm}^{2}\right)$.
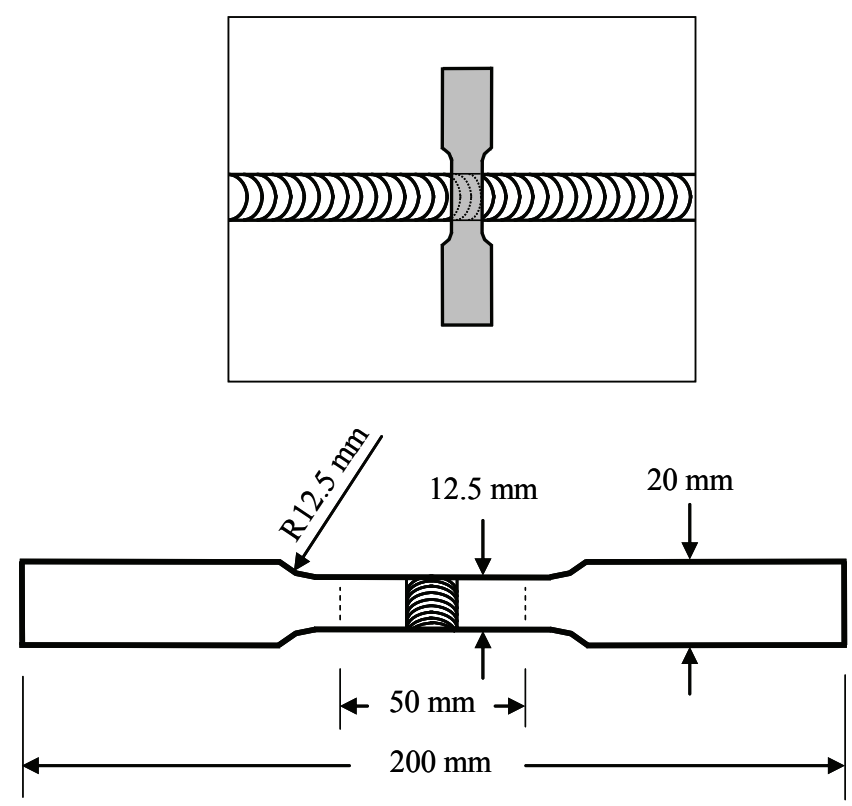

Fig. 4 Specimen of tensile coupon tests for the mechanical property characterization of the welded material.
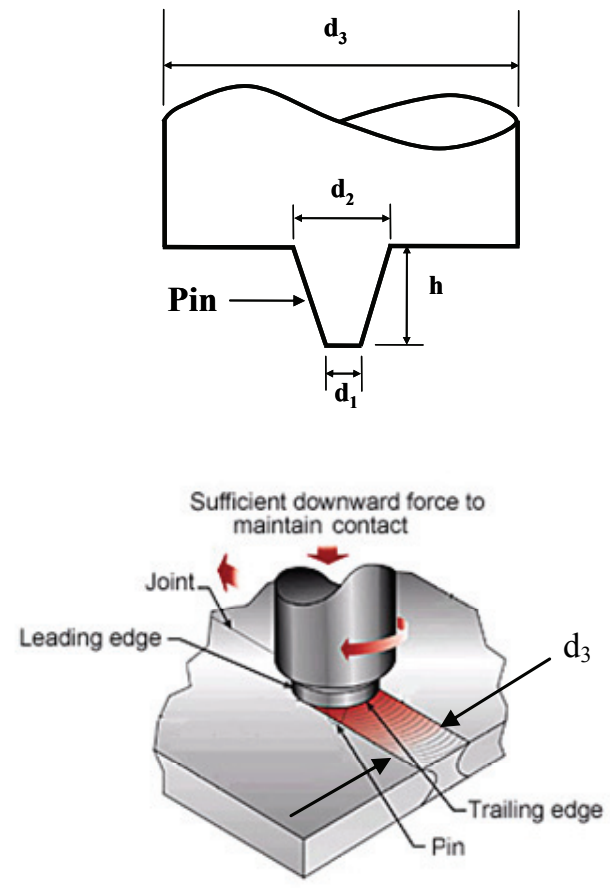

Fig. 5 Nomenclature for FSW tool size. 


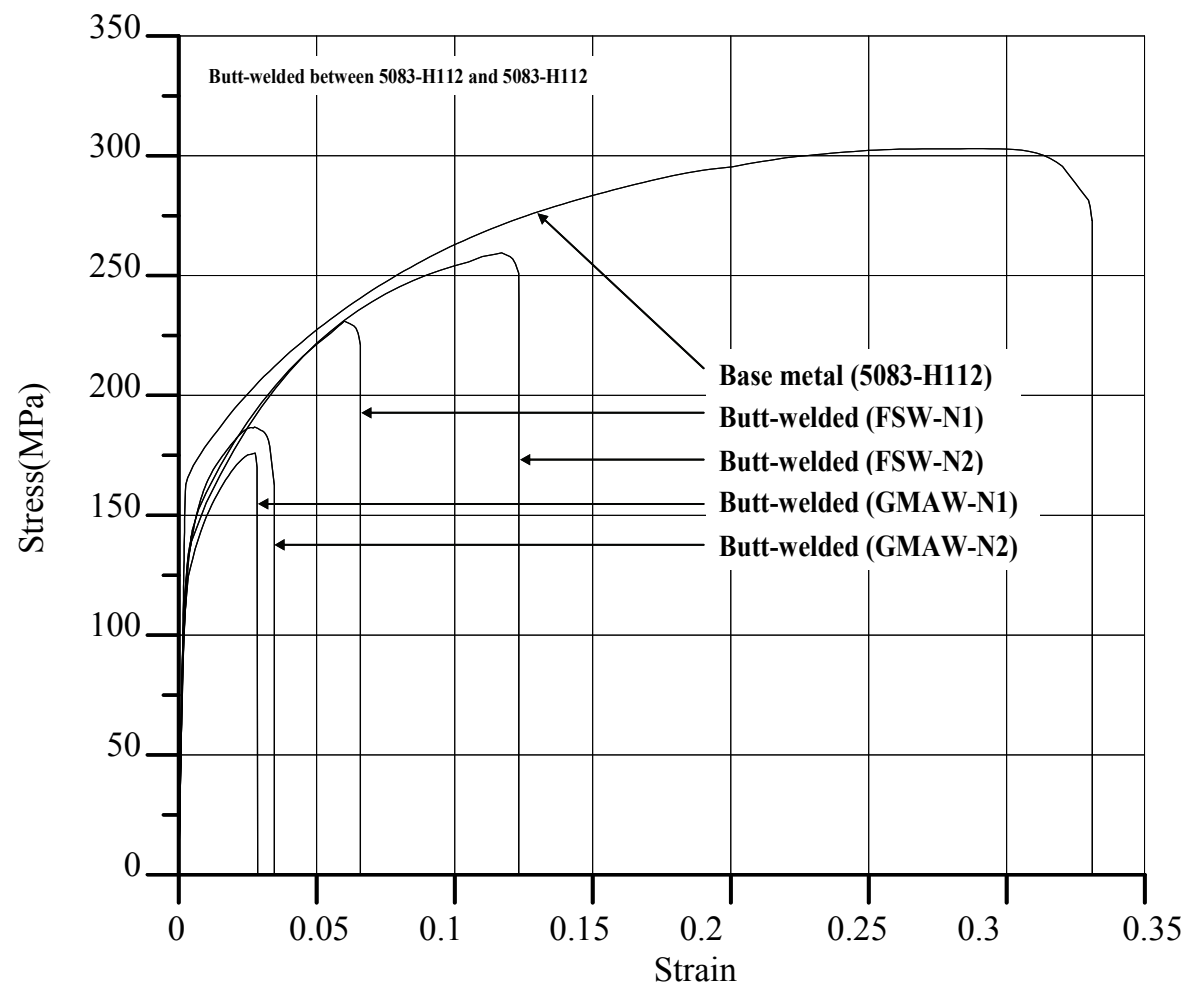

Fig . 6(a) Comparison of the stress versus strain curves for welded aluminum material fabricated by fusion welding and FSW 5083-H112 plus 5083-H112 - obtained from the tensile coupon tests.

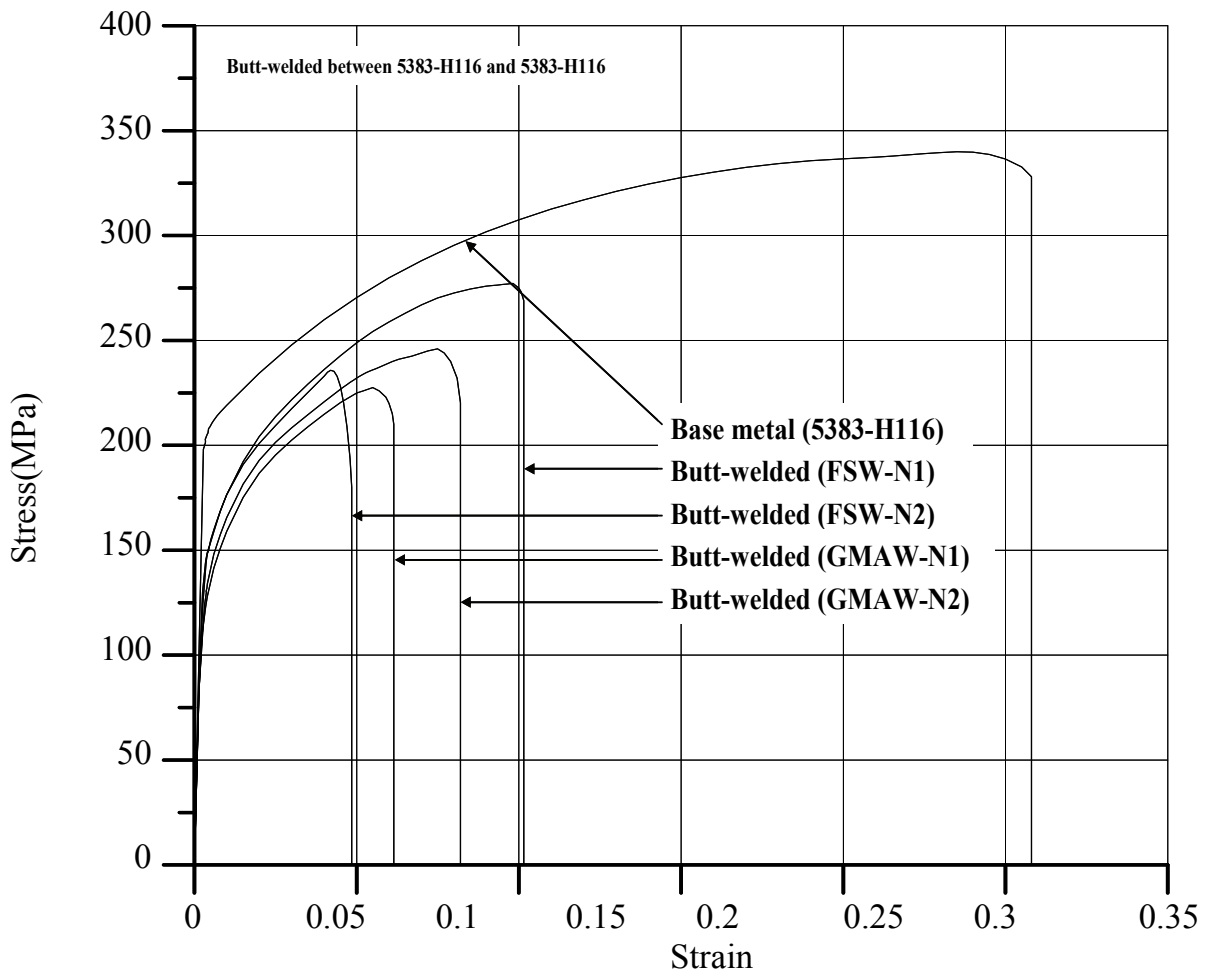

Fig. 6(b) Comparison of the stress versus strain curves for welded aluminum material fabricated by fusion welding and FSW - 5383-H116 plus 5383-H116 - obtained from the tensile coupon tests. 


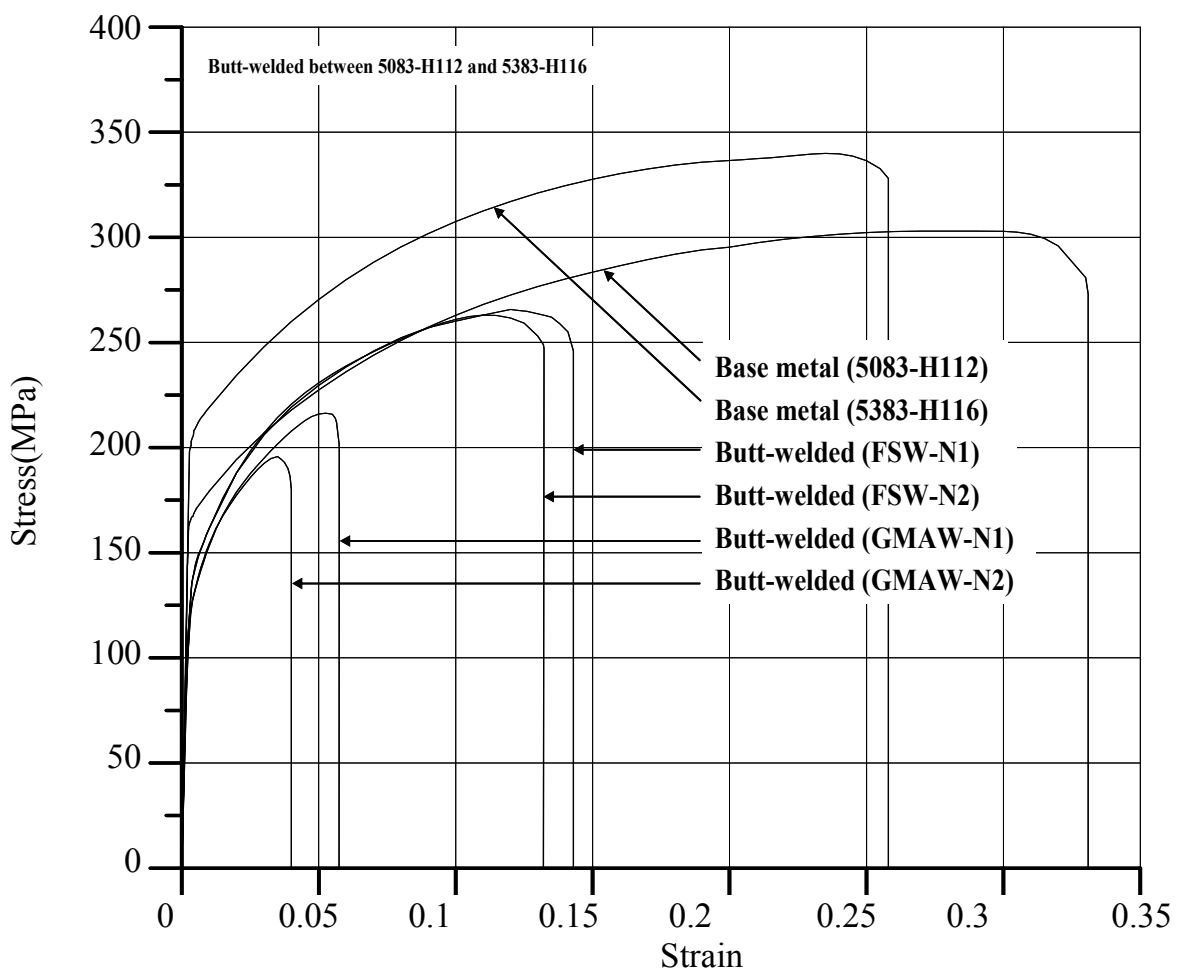

Fig. 6(c) Comparison of the stress versus strain curves for welded aluminum material fabricated by fusion welding and FSW 5083-H112 plus 5383-H116 - obtained from the tensile coupon tests.

Table 4 Summary of the mechanical properties of welded aluminum alloys, obtained from the tensile coupon tests.

\begin{tabular}{|c|c|c|c|c|c|}
\hline Material & Weld specimen & $\mathrm{E}\left(N / m m^{2}\right)$ & $\sigma_{\mathrm{Y}}\left(N / m m^{2}\right)$ & $\sigma_{\mathrm{T}}\left(N / m^{2}\right)$ & Elongation(\%) \\
\hline \multirow[t]{2}{*}{$5083-\mathrm{H} 11+5083-\mathrm{H} 112$} & GMAW-N1 & 71685 & 125 & 176 & 2.86 \\
\hline & GMAW-N2 & 68753 & 135 & 191 & 3.46 \\
\hline \multicolumn{2}{|c|}{ Average } & 70219 & 130 & 183.5 & 3.16 \\
\hline \multirow[t]{2}{*}{$5083-\mathrm{H} 112+5083-\mathrm{H} 112$} & FSW-N1 & 69178 & 137 & 236 & 6.58 \\
\hline & FSW-N2 & 70699 & 134 & 263 & 12.32 \\
\hline \multicolumn{2}{|l|}{ Average } & 69938.5 & 135.5 & 249.5 & 9.45 \\
\hline \multirow[t]{2}{*}{ 5083-H112 + 5383-H116 } & GMAW-N1 & 70733 & 124 & 224 & 5.73 \\
\hline & GMAW-N2 & 70469 & 125 & 204 & 3.99 \\
\hline \multicolumn{2}{|l|}{ Average } & 70601 & 124.5 & 214 & 4.86 \\
\hline \multirow[t]{2}{*}{ 5083-H112 + 5383-H116 } & FSW-N1 & 70131 & 137 & 271 & 14.44 \\
\hline & FSW-N2 & 70022 & 137 & 269 & 13.13 \\
\hline \multicolumn{2}{|c|}{ Average } & 70076.5 & 137 & 270 & 13.79 \\
\hline \multirow[t]{2}{*}{ 5383-H116 + 383-H116 } & GMAW-N1 & 68175 & 128 & 232 & 6.19 \\
\hline & GMAW-N2 & 68150 & 134 & 247 & 8.17 \\
\hline \multicolumn{2}{|l|}{ Average } & 68162.5 & 131 & 239.5 & 7.18 \\
\hline \multirow[t]{2}{*}{$5383-\mathrm{H} 116+5383-\mathrm{H} 116$} & FSW-N1 & 69810 & 147 & 285 & 10.15 \\
\hline & FSW-N2 & 70081 & 148 & 239 & 4.85 \\
\hline \multicolumn{2}{|l|}{ Average } & 69945.5 & 147.5 & 262 & 7.5 \\
\hline
\end{tabular}

Note: $\mathrm{E}=$ elastic modulus; $\sigma_{\mathrm{Y}}=$ yield strength; $\sigma_{\mathrm{T}}=$ ultimate tensile strength. 
Table 4 summarizes the mechanical properties of the butt-welded aluminum alloys, as obtained from the tensile coupon tests. Table 5 presents the minimum yield strength requirements for fusion-welded aluminum alloys. It is seen that the minimum requirements of mechanical properties for welded aluminum alloys are quite different depending on the institutions. Nevertheless, the results of the present study meet the minimum requirements of fusion-welded aluminum alloys, while any corresponding guidance for friction stir welded aluminum alloys does not exist yet.
It is noted that the tensile coupon tests were performed for butt welds only in the present study, and thus further study is needed to verify the tensile properties of the friction stir lap-welded material. A microscopic examination of the friction stir lap-welded material is recommended to find any defects associated with the width and depth of the molten metal thin layer which potentially cause delamination in preor post-collapse range of the structure under compressive actions involving buckling or crushing.

Table 5 Minimum yield strength requirements for fusion-welded aluminum alloys, as specified by various regulations $\left(\mathrm{N} / \mathrm{mm}^{2}\right)$.

\begin{tabular}{|c|c|c|c|c|c|}
\hline Alloy & ABS (2008) & DNV (2008) & AA (2005) & AWS (2004) & Alcan (2004) \\
\hline 5086-H0(E) & - & 92 & 95 & - & - \\
\hline 5086-H32(R) & 131 & 92 & 95 & 131 & - \\
\hline 5086-H111(E) & 124 & 92 & 95 & 124 & - \\
\hline 5086-H116(R) & 131 & 92 & 95 & 131 & - \\
\hline 5083-H111(E) & 145 & - & 110 & 145 & - \\
\hline 5083-H116(R) & 165 & 116 & 115 & 165 & 125 \\
\hline 5383-H111(E) & 145 & - & - & - & 145 \\
\hline 5383-H116(R) & 145 & 140 & - & - & 145 \\
\hline 5454-H111(E) & 110 & 76 & 85 & 110 & - \\
\hline 5454-H34(R) & 110 & 76 & 85 & 110 & - \\
\hline 5454-H32(R) & 110 & 76 & 85 & 110 & - \\
\hline 5456-H111(E) & 165 & - & - & 165 & - \\
\hline 5456-H116(R) & 179 & - & 125 & 179 & - \\
\hline $6061-\mathrm{T} 6(\mathrm{E}, \mathrm{R})^{*}$ & 138 & 105 & 105 & 138 & - \\
\hline 6061-T6(E,R) & 103 & 105 & 80 & 103 & - \\
\hline
\end{tabular}

Note: ${ }^{*}$ welded with 5356 filler; $(\mathrm{E})=$ extruded; $(\mathrm{R})=$ rolled; $\mathrm{ABS}=$ American Bureau of Shipping; $\mathrm{DNV}=$ Det Norske Veritas (Yield strength $\sigma_{1}$ is determined from the values of $f_{l}$ published by the equation $\sigma_{1}=f_{l} \times 240 / 1.1$ ); AA = Aluminum Association; AWS $=$ American Welding Society.

\section{DISCUSSION}

Welding reduces the mechanical properties or the tensile strength performance of materials, compared to those of base (unwelded) materials. It is observed that the tensile strength performance of friction stir welded aluminum alloys is superior to that of fusion welded aluminum alloys for joining materials between identical alloys or between dissimilar alloys. The trend of mechanical property reduction due to welding is more significant for 5083 alloy than 5383 alloy.

Compared to the fusion-welding process, that for FSW is considered to be more attractive, although there are some limitations to its application (Kramer, 2007; Paik, 2009).

The advantages of the FSW process primarily result from the fact that it works in the solid state at a low temperature that is below the melting point of the materials to be joined. 
This is in contrast to the fusion-welding process. Thus, the level of fabrication related-initial imperfections in structures built by FSW should subsequently be slight and/or less severe than those produced by fusion welds.

The limitations of FSW applications may include the following.

- The pins of the FSW tool are consumable, and their size (diameter and length) differs depending on the properties of the plates to be joined.

- The position of welding is limited due to the orientation of the FSW machine, including the tool. Fillet welding is not relevant because inclining the target plates and/or the FSW machine along the intersections to be joined between the plate and extrusion is not straightforward.

- Butt-joining is relevant, but there must be no obstacles around the FSW machine that can disturb the rotating and forwarding of the tool.

- Lap-joining is relevant, but the pin size must be carefully chosen.

- A keyhole is formed at the end of each weld, as shown in Fig. 7.

- The speed of FSW is usually slower than that of fusion welding.

- A weld nugget may form at the center of the weld.

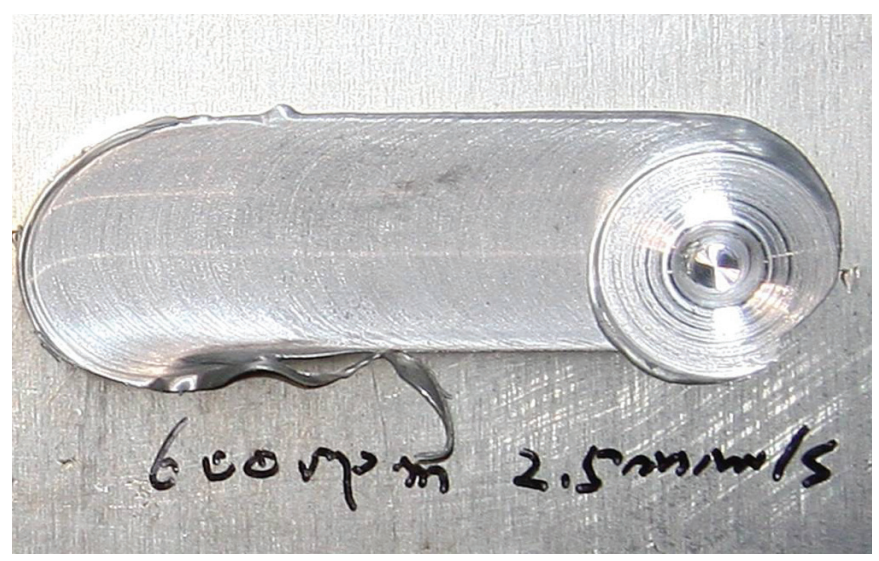

Fig.. 7 Keyhole at the end of the friction stir weld.

The mechanical property and strength performance in the friction stir welded region is affected by various parameters such as width and depth of molten thin layer, molten temperature, rotating and forwarding speeds, and possible quick cooling, etc. The quality assurance of the friction stir welded region can be performed by non-destructive test (NDT) methods to find any defects.

\section{CONCLUSIONS}

The objective of the present study has been to obtain test database on mechanical properties of friction stir welded aluminum alloys with the focus on 5083-H112 and 5383H116 alloys. A series of tensile coupon tests were undertaken on friction stir and fusion welded aluminum alloys as well as base (unwelded) alloys. Welded materials between dissimilar alloys as well as between identical alloys were also tested. The engineering stress-engineering strain relationships of tested alloys have been documented with the identification of their mechanical properties. The test database developed in the present study will be very useful for the design and building of aluminum ship structures fabricated by friction stir welding.

\section{ACKNOWLEDGEMENTS}

The present study was undertaken at the Lloyd's Register Educational Trust (LRET) Research Centre of Excellence, Pusan National University, Korea. The Lloyd's Register Educational Trust (LRET) is an independent charity working to achieve in transportation, science, engineering and technology education, training and research worldwide for the benefit of all. Thanks are due to graduate students at the Ship and Offshore Structural Mechanics Laboratory of the Pusan National University for their efforts regarding buckling collapse tests and nonlinear finite element method computations.

In addition, the author would like to thank Ship Structure Committee (SSC) for its financial and technical assistance. SSC is an inter-agency organization chaired by US Coast Guard with the goal of eliminating marine structural failures. Member agencies consist of American Bureau of Shipping (ABS), Defence Research Directorate Canada (DRDC), US Maritime Administration (MARAD), Military Sealift Command (MSC), Naval Sea Systems Command (NAVSEA), Transport Canada, Society of Naval Architects and Marine Engineers (SNAME) and the US Coast Guard (USCG). Without the SSC support, it certainly would not have been able to complete this project. Special thanks are due to the members of SSC Project Technical Committee chaired by Mr. Chao Lin, for their valuable comments and advices.

\section{REFERENCES}

AA, 2005. Aluminum design manual, Table 3.3-2. The Aluminum Association, Arlington, Virginia, USA.

ABS, 2006. Rules for material and welding, Part 2 Aluminum and fiber reinforced plastics. Chapter 5, Appendix 1, Table 2, American Bureau of Shipping, Houston, USA.

ALCAN Aerospace, Transportation and Industry, 2004. Aluminium and the Sea. Paris, France

AWS, 2004. Guide for aluminum hull welding, AWS D3.7. American Welding Society, USA.

Biallas, G. Braun, R. Dalle Donne, C. Staniek, G. and Kaysser, W.A., 1999. Mechanical properties and corrosion behavior of friction stir welded 2024-T3. Proceedings of the $1^{\text {st }}$ International Friction Stir Welding Symposium, Thousand Oaks, California. 
Collette, M.D., 2007. The impact of fusion welds on the ultimate strength of aluminum structures. Proceedings of $10^{\text {th }}$ International Symposium on Practical Design of Ships and Other Floating Structures (PRADS 2007), Houston, USA.

Colligan, K.J., 2004. Friction stir welding for ship construction. Concurrent Technologies Corporation, Harrisburg, PA.

Dawes, C.J. and Thomas, W.M., 1995. Friction stir joining of aluminum alloys. TWI Bulletin, The Welding Institute, November/December.

DNV, 2008. Rules for classification of high speed, light craft and naval surface craft. Part 3, Chapter 3, Section 2, Table B4, Oslo, Norway.

Hagstrom, J. and Sandstrom, R., 1998. Static and dynamic properties of joints in thin-walled aluminum extrusions, welded with different methods. Proceedings of $6^{\text {th }}$ International Conference on Aluminum Alloys, Toyohashi, Japan, pp.1447-1452.

Hashimoto, T. Nishikawa, N. Tazaki, S. and Enomoto, M., 1998. Mechanical properties of joints for aluminum alloys with friction stir welding process. Proceedings of $7^{\text {th }}$ International Conference on Joints in Aluminum, Cambridge, UK, 15-17 April 1998.

Kamioka, M. and Okubo, K., 2005. Studies on fatigue properties of friction stir welded joints in structural thin aluminum alloys. Proceedings of the $5^{\text {th }}$ International Forum on Aluminum Ships, Tokyo, Japan, 11-13 October 2005, pp.115-124.

Kramer, R., 2007. In-service performance of aluminum structural details. Ship Structure Committee Report, SSC-447, Washington DC.

LR, 2008. Lloyd's Register rules and regulations for the classification of special service craft. Vol.1, Part 2 Rules for the maintenance, testing and certification of materials, Chapter 8 - Aluminum alloys and Part 7 - Hull construction in aluminum, London, UK.

Mahoney, M.W. Rhodes, C.G. Flintoff, J.G. Spurling, R.A. and Bingel, W.H., 1998. Properties of friction stir welded 7075-T651 aluminum. Metallurgical and Materials Transactions A, 29A, pp.1955-1964.

Masubuchi, K., 1980. Analysis of welded structures. Pergamon Press, Oxford, UK.

Midling, O.T. Oosterkamp, L.D. and Bersaas, J., 1998. Friction stir welding - Process and applications, Proceedings of $7^{\text {th }}$ International Conference on Joints in Aluminum, Cambridge, UK, 15-17 April 1998.

Paik, J.K., 2009. Buckling collapse testing of friction stir welded aluminum stiffened plate structures. Ship Structure Committee Report, SR-1454, Washington DC.
Paik, J.K. Thayamballi, A.K. Ryu, J.Y., Jang J.H., Seo, J.K. Park, S.W. Seo, S.K. Andrieu, C. and Kim, N.I., 2008. Mechanical collapse testing on aluminum stiffened panels for marine applications. Ship Structure Committee Report, SSC-451, Washington DC.

Peel, M. Steuwer, A. Preuss, M. and Withers, P.J., 2003. Microstructure, mechanical properties and residual stresses as a function of welding speed in aluminum AA5083 friction stir welds. Acta Materialia, 51, pp.4791-4801.

Rhodes, C.G. Mahoney, M.W. and Bingel, W.H., 1997. Effects of friction stir welding on microstructure of 7075 aluminum. Scripta Materialia, 36(1), pp. 69-75.

Sanderson, A. Punshon, C.S. and Russell, J.D., 2000. Advanced welding processes for fusion reactor fabrication. Fusion Engineering and Design, 49-50, pp.77-87.

Sielski, R.A., 2007. Review of structural design of aluminum ships and crafts. Trans. SNAME, 115, pp.1-30.

Sielski, R.A., 2008. Research needs in aluminum structure. Ships and Offshore Structures, 3(1), pp.57-65.

Thomas, W.M., 1998. Friction stir welding and related friction process characteristics. Proceedings of the $7^{\text {th }}$ International Conference on Joints in Aluminum (INALCO'98), Cambridge, UK, April 1998.

Thomas, W.M. and Nicholas, E.D., 1997. Friction stir welding for the transportation industry. Materials \& Design, Vol. 18, Nos. 4/6, pp.269-273.

Thomas, W.M. Nicholas, E.D. Needham, J.C. Murch, P. Temple-Smith, P. and Dawes, C.J., 1991. Friction-stir butt welding. GB Patent Application No. 9125978.8, International Patent Application PCT/GB92/02203, 6 December 1991.

Thomas, W.M. Nicholas, E.D. Needham, J.C. Murch, P. Temple-Smith, P. and Dawes, C.J., 1995. Friction stir welding, US Patent No. 5460317, 25 October 1995.

Thomas, W.M. Nicholas, E.D. Watts, E.R. and Staines, D.G., 2002. Friction based welding technology for aluminum, Proceedings of the $8^{\text {th }}$ International Conference on Aluminum Alloys, Cambridge, UK, 2-5 July 2002.

Thomas, W.M. Staines, D.G. Oakley, P.J. and Watts, E.R., 2005. Friction stir welding for aluminum applications Process development. Proceedings of the $5^{\text {th }}$ International Forum on Aluminum Ships, Tokyo, Japan, 11-13 October 2005, pp.137-144. 